\title{
The E3 ubiquitin ligase Itch regulates expression of transcription factor Foxp3 and airway inflammation by enhancing the function of transcription factor TIEG1
}

\author{
K Venuprasad ${ }^{1}$, Haining Huang ${ }^{1}$, Yousuke Harada ${ }^{1}$, Chris Elly ${ }_{1}^{1}$, Malayannan \\ Subramaniam $^{2}$, Thomas Spelsberg ${ }^{2}$, Jin $\mathrm{Su}^{1}$, and Yun-Cai Liu ${ }^{1}$ \\ 1 Division of Cell Biology, La Jolla Institute for Allergy and Immunology, La Jolla, California 92037, USA
}

2 Mayo Clinic and Foundation, Rochester, Minnesota 55905, USA

\begin{abstract}
Transforming growth factor- $\beta$ (TGF- $\beta$ ) signaling in naive $\mathrm{T}$ cells induces expression of the transcription factor Foxp3, a 'master' regulator of regulatory $\mathrm{T}$ cells $\left(\mathrm{T}_{\text {reg }}\right.$ cells). However, the molecular mechanisms leading to Foxp3 induction remain unclear. Here we show that $\mathrm{Itch}^{-l-} \mathrm{T}$ cells were resistant to TGF- $\beta$ treatment and had less Foxp3 expression. The E3 ubiquitin ligase Itch associated with and promoted conjugation of ubiquitin to the transcription factor TIEG1. Itch cooperated with TIEG1 to induce Foxp3 expression, which was reversed by TIEG1 deficiency. Functionally, 'TGF- $\beta$-converted' $\mathrm{T}_{\text {reg }}$ cells generated from TIEG1-deficient mice were unable to suppress airway inflammation in vivo. These results suggest TIEG and Itch contribute to a ubiquitindependent nonproteolytic pathway that regulates inducible Foxp3 expression and the control of allergic responses.
\end{abstract}

\begin{abstract}
Allergic asthma is a chronic inflammatory disease of the airways characterized by higher serum immunoglobulin E (IgE) concentrations, airway hyper-responsiveness, excessive airway mucus production, lung eosinophilia and airway remodeling. Differentiation of $\mathrm{CD} 4^{+} \mathrm{T}$ cells into $T$ helper type $2\left(\mathrm{~T}_{\mathrm{H}} 2\right)$ cells renders them able to produce the cytokines interleukin 4 (IL-4), IL-5 and IL-13, which are critical for driving asthmatic pathogenesis ${ }^{1,2}$. The induction of $\mathrm{T}_{\mathrm{H}} 2$ differentiation is regulated by many factors, including the properties of the antigens, the duration of stimulation, and genetic factors. In addition, the $\mathrm{T}_{\mathrm{H}}$ 2-mediated immune responses are counterbalanced by tolerogenic mechanisms that prevent excessive reactions. One of the tolerance mechanisms involves regulatory $\mathrm{T}$ cells $\left(\mathrm{T}_{\text {reg }}\right.$ cells $)$, which limit allergic responses ${ }^{3}$. In mouse models of allergic asthma, repeated delivery of antigen to the respiratory tract results in inhibition of allergic responses to the same antigen after subsequent challenges ${ }^{4}$. Published studies have shown that repeated treatment with a low dose of antigen induces the generation of Foxp $3^{+} \mathrm{CD} 4{ }^{+} \mathrm{CD} 25^{+} \mathrm{T}_{\text {reg }}$ cell population, which accounts for the attenuation of $\mathrm{T}_{\mathrm{H}}$ 2-mediated airway inflammation ${ }^{5,6}$. $\mathrm{T}_{\text {reg }}$ cells represent a unique subpopulation of $\mathrm{CD}^{+} \mathrm{T}$ cells that suppress the effector function of other types of $\mathrm{T}$ cells and
\end{abstract}

Correspondence should be addressed to Y.-C.L. (yuncail@liai.org).

Note: Supplementary information is available on the Nature Immunology website.

AUTHOR CONTRIBUTIONS

K.V. contributed to the design and execution of the experiments and data interpretation and helped prepare the manuscript; H.H., Y.H., C.E. and J.S. did the molecular and biochemical experiments and provided technical assistance; S.M. and T.S. provided mice; and Y.-

C.L. supervised the project and helped prepare the manuscript.

Published online at http://www.nature.com/natureimmunology

Reprints and permissions information is available online at http://npg.nature.com/reprintsandpermissions 
are critical regulators of the maintenance of self-tolerance ${ }^{7,8}$. However, the mechanisms underlying the regulation of the generation of $\mathrm{T}_{\text {reg }}$ cells during $\mathrm{T}_{\mathrm{H}}$ 2-mediated allergic responses remain unclear.

Transforming growth factor- $\beta$ (TGF- $\beta$ ) is a multifunctional cytokine that has been linked to the regulation of immune responses ${ }^{9}$. Ablation of either TGF- $\beta$ or its receptor results in excessive $\mathrm{T}$ cell responses and severe autoimmunity $10-13$. TGF- $\beta$ is important in the conversion of naive $\mathrm{CD}^{+} \mathrm{T}$ cells into Foxp $3^{+} \mathrm{T}_{\text {reg }}$ cells in vitro and the maintenance of $\mathrm{T}_{\text {reg }}$ cells in vivo $11,{ }^{14-16}$. It has been shown that TGF- $\beta$, in cooperation with IL-6, promotes the development of IL-17-producing T helper cells ( $\mathrm{T}_{\mathrm{H}^{-}} 17$ cells), a $\mathrm{T}$ helper cell subset involved in autoimmune and inflammatory responses ${ }^{17}$. At present, the intracellular signaling pathways that link TGF- $\beta$ signaling to diverse or even opposing $\mathrm{T}$ cell functions remain mostly unclear.

Itch is an E3 ubiquitin ligase originally identified by genetic analysis of a mutant mouse with aberrant immunological phenotypes and constant scratching of the skin ${ }^{18}$. Functional analysis of Itch ${ }^{-1-} \mathrm{T}$ cells showed that they are biased toward the differentiation of $\mathrm{T}_{\mathrm{H}} 2$ cells with augmented $\mathrm{T}_{\mathrm{H}} 2$ cytokine production and serum $\operatorname{IgE}$ titers 19 . One mechanism by which Itch regulates $\mathrm{T}$ cell responses is the induction of $\mathrm{T}$ cell anergy in which $\mathrm{T}$ cells become unresponsive after restimulation ${ }^{20}$. In a mouse model of $\mathrm{T}$ cell tolerance, systemic injection of a high dose of soluble antigen failed to block the development of airway inflammation in $\mathrm{Itch}^{-/-}$mice, which indicates that Itch is important in the tolerogenic process of $\mathrm{T}_{\mathrm{H}} 2$ cells 21 . However, detailed mechanisms underlying Itch-mediated protein ubiquitination in immune tolerance and allergic responses remain to be investigated.

To address those issues, we investigated whether Itch is involved in Foxp3 expression and the generation of $T_{\text {reg }}$ cells. Here we provide both genetic and biochemical evidence that Itch is critically involved in the generation of $\mathrm{T}_{\text {reg }}$ cells by targeting ubiquitination of the transcription factor TIEG1 (TGF- $\beta$-inducible early gene 1 product) and promoting its transcriptional activation. This nonproteolytic pathway is important in the regulation of $\mathrm{T}_{\mathrm{H}} 2$-mediated allergic responses.

\section{RESULTS}

\section{Itch $^{-/-}$naive $\mathrm{T}$ cells are resistant to $\mathrm{T}_{\text {reg }}$ cell-mediated suppression}

Because $T_{\text {reg }}$ cells have been linked to inhaled antigen-induced airway inflammation and Itch is involved in the tolerance induction of $\mathrm{T}_{\mathrm{H}} 2$ cells 5,21 , we sought to determine whether Itch deficiency affects the generation of $\mathrm{T}_{\text {reg }}$ cells or $\mathrm{T}_{\text {reg }}$ cell-mediated suppression. First we analyzed the percentage of naturally occurring $\mathrm{CD} 4^{+} \mathrm{CD} 25^{+} \mathrm{T}_{\text {reg }}$ cells in the thymus, spleen and lymph nodes and found no obvious difference in the ratio of $T_{\text {reg }}$ cells in wild-type versus Itch ${ }^{-1-}$ mice (Supplementary Fig. 1a online). Similarly, $\mathrm{CD} 4^{+} \mathrm{CD} 25^{+} \mathrm{T}_{\text {reg }}$ cells from both types of mice had similar expression of other $\mathrm{T}_{\text {reg }}$ cell markers such as GITR and CTLA-4 (Supplementary Fig. 1b). These results suggest that Itch is not involved in the development of naturally occurring $\mathrm{CD} 25^{+} \mathrm{CD} 4^{+} \mathrm{T}_{\text {reg }}$ cells.

Next we determined by in vitro coculture assay whether there was functional alteration of $\mathrm{T}_{\text {reg }}$ cells due to Itch ablation. We labeled $\mathrm{CD} 4{ }^{+} \mathrm{CD} 25^{-} \mathrm{T}$ cells sorted from both wild-type and Itch ${ }^{-/-}$mice with the cytosolic dye CFSE and incubated them with flow cytometry-sorted $\mathrm{CD} 4{ }^{+} \mathrm{CD} 25^{+} \mathrm{T}_{\text {reg }}$ cells from those mice. We stimulated the cells with antibody to CD3 (antiCD3) in the presence of irradiated antigen-presenting cells and assessed cell division by flow cytometry of CFSE dilution. $\mathrm{T}_{\text {reg }}$ cells from wild-type mice and Itch $^{-1-}$ mice had a similar extent of inhibition of the division of $\mathrm{CD} 4^{+} \mathrm{CD} 25^{-} \mathrm{T}$ cells from wild-type mice (Fig. 1a). However, $\mathrm{T}_{\text {reg }}$ cells from either wild-type or $\mathrm{Itch}^{-1-}$ mice failed to inhibit the division of $\mathrm{CD} 4^{+} \mathrm{CD} 25^{-} \mathrm{T}$ cells from $\mathrm{Itch}^{-/-}$mice. To further confirm and quantify that finding, we 
analyzed thymidine incorporation in a similar coculture assay. As in the CFSE dilution experiment, Itch ${ }^{-1} \mathrm{CD} 4^{+} \mathrm{CD} 25^{-} \mathrm{T}$ cells were not responsive to the suppressive effect of $\mathrm{T}_{\text {reg }}$ cells from either wild-type or Itch ${ }^{-/-}$mice (Fig. 1b). These results suggest that Itch $^{-/-}$ responder $\mathrm{T}$ cells are not susceptible to $\mathrm{T}_{\text {reg }}$ cell-mediated inhibition.

Published studies have documented that TGF- $\beta$ is a critical cytokine in $\mathrm{T}_{\text {reg }}$ cell-mediated suppression of T cells 9 . To understand the mechanisms underlying the resistance of $\mathrm{CD}^{+} \mathrm{CD} 25^{-}$Itch $^{-1-} \mathrm{T}$ cells to treatment with $\mathrm{T}_{\text {reg }}$ cells, we first examined the effect of TGF$\beta$ on the inhibition of $\mathrm{T}$ cell proliferation. We stimulated $\mathrm{CD} 4^{+} \mathrm{CD} 25^{-} \mathrm{T}$ cells from wild-type and $\mathrm{Itch}^{-1-}$ mice with anti-CD3 plus anti-CD28 in the presence of various amounts of TGF$\beta$. As expected, wild-type $\mathrm{T}$ cells showed less proliferation in the presence of increasing amounts of TGF- $\beta$ (Fig. 1c). However, Itch ${ }^{-1-}$ T cells were much less responsive to TGF- $\beta$ treatment, even with a higher concentration of TGF- $\beta$.

\section{Itch affects the TGF- $\beta$-mediated conversion of $T_{\text {reg }}$ cells}

It is known that TGF- $\beta$ can convert $\mathrm{CD} 4^{+} \mathrm{CD} 25^{-} \mathrm{T}$ cells into Foxp $3^{+} \mathrm{T}_{\text {reg }}$ cells in vitro ${ }^{14,15}$. To further understand the effect of Itch deficiency on TGF- $\beta$ signaling in T cells, we examined the Foxp 3 expression in both wild-type and Itch ${ }^{-1-} \mathrm{CD} 4{ }^{+} \mathrm{CD} 25^{-} \mathrm{T}$ cells after incubation with TGF- $\beta$. Treatment with TGF- $\beta$ resulted in upregulation of Foxp 3 transcription and Foxp3 protein expression in wild-type T cells (Fig. 2a,b). Itch deficiency resulted in much less Foxp 3 expression. We next assessed the functional properties of the in vitro-converted $\mathrm{T}_{\text {reg }}$ cells by coculture assay. In vitro-converted $\mathrm{T}_{\text {reg }}$ cells from wild-type mice showed suppressive activity toward $\mathrm{CD} 4{ }^{+} \mathrm{CD} 25^{-} \mathrm{T}$ cells, whereas TGF- $\beta$-treated Itch ${ }^{-1-} \mathrm{T}$ cells were much less inhibitory (Fig. 2c). We then reconstituted Foxp3 expression by retroviral transduction of wildtype and $I t c h^{-/-} \mathrm{T}$ cells and found that the defective inhibitory function of Itch ${ }^{-1-} \mathrm{T}$ cells was compensated by Foxp3 expression (Supplementary Fig. 2a,b online).

Because Itch ${ }^{-1-} \mathrm{T}$ cells are biased toward $\mathrm{T}_{\mathrm{H}} 2$ cell differentiation, we examined the involvement of IL-4 in Foxp3 expression. Intracellular staining of individual T cells showed that the lower Foxp3 expression and higher IL-4 production were independent events and that neutralizing IL-4 in the cell culture did not affect Foxp3 expression (Fig. 2d,e). These results collectively suggest that loss of Itch alters TGF- $\beta$ signaling in T cells and affects TGF- $\beta$ induced Foxp3 expression, even though Itch does not affect the development of naturally occurring $\mathrm{CD} 4^{+} \mathrm{CD} 25^{+} \mathrm{T}_{\text {reg }}$ cells.

\section{TIEG1 as a target of Itch}

To understand the mechanisms underlying the hyporesponsiveness of Itch ${ }^{-/-} \mathrm{T}$ cells to TGF$\beta$ treatment, we analyzed intracellular signaling pathways in wild-type and $I t c h^{-/-} \mathrm{T}$ cells. First we assessed the phosphorylation status of signal transducer Smad2 proteins after TGF- $\beta$ stimulation. In repeated experiments, we found that Itch deficiency did not overtly affect Smad2 phosphorylation (Fig. 3a). We also measured the abundance of Smad2, Smad4 and Smad7 protein and noted little difference in wild-type versus $I_{t c h}{ }^{-1-} \mathrm{T}$ cells for up to $8 \mathrm{~h}$ of stimulation (data not shown). These results suggest that proximal 'downstream' signaling of the TGF- $\beta$ receptor is relatively normal in Itch ${ }^{-1-} \mathrm{T}$ cells.

We next sought signaling molecules further 'downstream' that might act as target proteins for Itch. One putative target was TIEG1, which is rapidly induced after TGF- $\beta$ stimulation and functionally mimics TGF- $\beta$-mediated transcriptional events in transient transfection systems ${ }^{22}$. Structurally, TIEG1 contains many proline-rich sequences that may be recognized by Itch 'WW' domains (which have two highly conserved tryptophan residues) and zinc-finger DNA-binding domains that mediate gene transcription. To test our hypothesis, we generated a fusion protein of glutathione $S$-transferase and TIEG1 (GST-TIEG1) and did a precipitation 
assay with lysates of primary mouse T cells. GST-TIEG1 precipitated Itch, but GST alone did not (Fig. 3b), and this association was not dependent on stimulation with TGF- $\beta$ (Fig. 3c). The interaction seemed to be mediated by Itch WW domains, as GST-WW precipitated TIEG1 from the mouse T cell lysates (Fig. 3d). Finally, we determined by coimmunoprecipitation assay whether this interaction occurred endogenously in T cells. Itch was 'coimmunopurified' with a TIEG1-specific antibody and TIEG1 was coprecipitated by anti-Itch (Fig. 3e). These results suggest that Itch forms a complex with TIEG1 in T cells.

We next determined whether Itch acts as an E3 ubiquitin ligase for TIEG1. For this, we expressed Myc-tagged TIEG1 together with wild-type Itch or a ligase-deficient 'Itch-CA' mutant $^{19}$, in which the active-site cysteine residue at position 822 is substituted with alanine, in human embryonic kidney $293 \mathrm{~T}$ cells, along with hemagglutinin-tagged ubiquitin. Wild-type Itch induced the conjugation of ubiquitin to TIEG1, as shown by the formation of slowly migrating high-molecular-weight species (Fig. 3f). However, loss of the E3 ligase activity of Itch abrogated the conjugation of ubiquitin to TIEG1. We detected a low-molecular-weight band in cells expressing Itch; this represented a single ubiquitin conjugated to TIEG1.

Coexpression of an active form of the TGF- $\beta$ receptor enhanced Itch-promoted conjugation of ubiquitin to TIEG1 in both the mono- and poly-ubiquitinated forms (Fig. $3 \mathrm{~g}$ ). We detected the monoubiquitinated form in the nuclear fraction of cells expressing Itch (Fig. 3h). These results indicate that Itch functions as an E3 ligase for TIEG1.

\section{Involvement of TIEG1 in Foxp3 expression}

To investigate the involvement of TIEG1 in Foxp 3 expression, we first tested whether TIEG1 affected transactivation of the Foxp 3 promoter in a luciferase reporter assay. Transient expression of TIEG1 resulted in greater Foxp3-driven luciferase activity after stimulation with TGF- $\beta$ (Fig. 4a). Notably, coexpression of Itch plus TIEG1 greatly augmented transactivation of the Foxp 3 promoter, whereas such enhancement was abolished by coexpression of the ligasedeficient Itch-CA mutant plus TIEG1. To determine whether TIEG1 directly binds to the Foxp3 promoter, we did an electrophoretic mobility-shift assay (EMSA) with a probe corresponding to the putative 'Sp1' sequences in the Foxp3 promoter. The mobility of the radiolabeled probe was retarded by the formation of complexes with cellular proteins in TGF$\beta$ stimulated T cells, and these were recognized by anti-TIEG1 (Fig. 4b). In addition, DNAbinding ability was almost completely abolished in TGF- $\beta$-stimulated Itch ${ }^{-l-}$ T cells (Fig. 4c). Furthermore, anti-TIEG1 precipitated Foxp 3 promoter region fragments in TGF- $\beta$-stimulated wild-type T cells but not in Itch ${ }^{-1-} \mathrm{T}$ cells (Fig. 4d), which supported the idea that Itch is an essential regulator of TIEG1-mediated transactivation.

We further tested the importance of TIEG1 ubiquitination in 293T cells transfected with hemagglutinin-tagged ubiquitin and TIEG1 plus Itch plasmids. Antibody to hemagglutinin (ubiquitin), which in principle precipitates ubiquitin-labeled TIEG1, also caused 'supershifting' of the TIEG1-DNA probe complex (Fig. 4e). The defects in Foxp3 expression and binding of TIEG1 to Foxp3 promoter in Itch ${ }^{-l-}$ T cells were 'rescued' by reconstitution with wild-type Itch but not with the ligase-deficient Itch-CA mutant (Fig. 4f,g).

Because Itch promoted both monoubiquitination and polyubiquitination of TIEG1, we tested whether Itch affects the stability of TIEG1. We stimulated wild-type and Itch ${ }^{-/-} \mathrm{T}$ cells with TGF- $\beta$ and induced TIEG1 expression $2 \mathrm{~h}$ later and found that the amount of TIEG1 was similar in these cells over a period of $8 \mathrm{~h}$ of incubation (Fig. 5a). To identify a direct function for TIEG1 in Foxp3 expression, we expressed TIEG1 in mouse CD4 ${ }^{+} \mathrm{T}$ cells by retroviral transduction and measured Foxp3 protein expression. TIEG1 expression resulted in Foxp3 expression in wild-type $\mathrm{CD}^{+} \mathrm{T}$ cells (Fig. $5 \mathrm{~b}$ ). However, $\mathrm{Itch}^{-1-} \mathrm{T}$ cells had much less induction of Foxp3. We also quantified Foxp3 by immunoblot analysis with a Foxp3-specific antibody. Itch ${ }^{-1-} \mathrm{T}$ cells transduced with TIEG1 had less Foxp3 expression in unstimulated or 
TGF- $\beta$-stimulated conditions (Fig. 5c). These results show that TIEG1 is a positive regulator of Foxp3 expression and that its activity is dependent on Itch-mediated ubiquitination.

\section{TIEG1 ablation affects Foxp3 expression and $T_{\text {reg }}$ cell function}

To further elucidate the involvement of TIEG1 in Foxp3 expression, we compared the responsiveness of wild-type and TIEG1-deficient T cells to treatment with TGF- $\beta$. Like Itch $^{-1-} \mathrm{T}$ cells, TIEG1-deficient $\mathrm{T}$ cells were resistant to TGF- $\beta$-induced inhibition of proliferation (Fig. 6a). The development of naturally occurring $\mathrm{T}_{\text {reg }}$ cells was slightly impaired in TIEG1-deficient mice (Supplementary Fig. 3 online). The difference was much more obvious for TGF- $\beta$-induced Foxp3 expression in the in vitro culture system, with TIEG1deficient $T$ cells having much less Foxp3 expression after TGF- $\beta$ stimulation (Fig. $6 \mathrm{~b}$ ). We also examined the biological function of 'TGF- $\beta$-converted' $T_{\text {reg }}$ cells from both wild-type and TIEG1-deficient mice in the coculture assay and found that TGF- $\beta$-treated TIEG1-deficient $\mathrm{CD} 4^{+} \mathrm{T}$ cells had a much less inhibitory effect on the responder T cells than did TGF- $\beta$-treated wild-type $\mathrm{CD}^{+}{ }^{+} \mathrm{T}$ cells (Fig. 6c). We also tested the involvement of Jun proteins, another target of Itch ${ }^{19}$, in Foxp3 expression by 'knockdown' with small interfering RNA and found that lower expression of JunB and c-Jun did not affect Foxp3 expression (Supplementary Fig. 4 online). In addition, TIEG1 did not associate with Cbl-b (Supplementary Fig. 5 online), another E3 ligase involved in Foxp3 expression ${ }^{30}$. These results provide genetic evidence that TIEG1 is involved in TGF- $\beta$-induced Foxp3 expression and the suppressive function of adaptive $\mathrm{T}_{\text {reg }}$ cells.

We then investigated whether reconstitution of TIEG1 in TIEG1-deficient T cells 'rescued' the defect in Foxp3 expression. Re-expression of TIEG1 restored Foxp3 expression in TIEG1deficient cells to expression similar to that of wild-type T cells after TGF- $\beta$ stimulation (Fig. 7a). Further functional studies showed that like $I_{t c h}{ }^{-1-} \mathrm{T}$ cells, TIEG1-deficient $\mathrm{CD} 4^{+} \mathrm{CD} 25^{-}$responder $\mathrm{T}$ cells were also resistant to the inhibitory effect of $\mathrm{T}_{\text {reg }}$ cells (Fig. $7 b)$. In addition, reconstitution of TIEG1 in TIEG1-deficient $T$ cells restored the susceptibility of these cells to inhibition by $\mathrm{T}_{\text {reg }}$ cells. However, over-expression of TIEG1 in Itch ${ }^{-1-} \mathrm{T}$ cells did not affect their resistance to $T_{\text {reg }}$ cell-mediated inhibition.

\section{TIEG1 regulates $T_{\text {reg }}$ cell-mediated airway inflammation}

A published study has documented that TGF- $\beta$-converted $\mathrm{T}_{\text {reg }}$ cells can suppress antigeninduced airway inflammation ${ }^{14}$. To further understand the functional implication of the Itchregulated TIEG1-ubiquitination pathway in immune responses, we did adoptive transfer experiments by injecting mice with TGF- $\beta$-converted T cells from both wild-type and TIEG1deficient mice, then inducing allergic responses with ovalbumin (OVA) antigen. Consistent with the previous study ${ }^{14}$, TGF- $\beta$-converted $\mathrm{T}_{\text {reg }}$ cells from wild-type mice suppressed allergic responses, reflected by less lung inflammation (Fig. 8a), less IL-4 production and eosinophil infiltration (Fig. 7b,c), and lower serum IgE concentrations (Fig. 7d). In contrast, TGF- $\beta$ treated $\mathrm{T}$ cells from TIEG1-deficient mice failed to inhibit the OVA antigen-induced allergic responses. However, adoptive transfer of TGF- $\beta$-treated, TIEG1-reconstituted T cells from both wild-type and TIEG1-deficient mice resulted in much less airway inflammation (Fig. 7). In addition, Itch ${ }^{-/}$mice showed similar resistance to tolerance induction and excessive airway inflammation after intranasal antigen exposure (Supplementary Figs. 6-10 online). These results indicate that TIEG1 is critical to $\mathrm{T}_{\text {reg }}$ cell-regulated allergic responses.

\section{DISCUSSION}

Accumulating evidence indicates that TGF- $\beta$ signaling is important in the expression of Foxp3, the 'master regulator' of the development and function of $\mathrm{T}_{\text {reg }}$ cells; however, the intracellular signaling mechanisms remain mostly unclear. Here we have used both genetic and biochemical 
approaches to show that Itch-mediated ubiquitination of TIEG1, a 'downstream' target of TGF$\beta$ signaling, is critical for Foxp3 expression. Notably, unlike ubiquitination of other target proteins for Itch, such as JunB, conjugation of ubiquitin to TIEG1 enhanced its transcriptional activation of the Foxp 3 promoter and Foxp 3 expression. Involvement of TIEG1 in the function of $\mathrm{T}_{\text {reg }}$ cells was further manifested by the defect of TGF- $\beta$-converted $\mathrm{T}_{\text {reg }}$ cells from TIEG1deficient mice in inhibiting $\mathrm{T}$ cell proliferation in vitro and antigen-induced airway inflammation in vivo. Thus, our study has demonstrated a ubiquitin-dependent, protein degradation-independent transcriptional activation pathway that is important in $\mathrm{T}_{\text {reg }}$ cell function and $\mathrm{T}_{\text {reg }}$ cell-regulated allergic responses.

TIEG1 is a member of the Sp1-like family of zinc-finger transcription factors; it contains transcriptional regulatory domains at its amino terminus and three DNA-binding zinc-finger motifs ${ }^{23}$. TIEG1 is rapidly upregulated after treatment of osteoblast cells with TGF- $\beta$, and ectopic expression of TIEG1 mimics TGF- $\beta$ signaling in such cells ${ }^{23}$, whereas TIEG1 ablation results in defective osteoblast function ${ }^{24}$. Relevant to our study here, TIEG1 is upregulated in both naturally occurring $\mathrm{T}_{\text {reg }}$ cells 25 and in vitro-stimulated $\mathrm{T}$ cells. We found that transient expression of TIEG1 resulted in upregulation of Foxp3 promoter-driven luciferase activity and Foxp3 expression in primary T cells, a finding supported by the lower Foxp3 expression in TIEG1-deficient T cells. Sequence scanning of Foxp3 promoter has identified a GC-rich region as a potential binding region for the $\mathrm{Sp} 1$ family of transcription factors ${ }^{26}$. Indeed, using this particular GC-rich sequence as a probe, we have demonstrated by EMSA that it specifically bound to TIEG1. Notably, such binding was much lower in Itch ${ }^{-1-}$ T cells after TGF- $\beta$ stimulation. Our results suggest that Itch-promoted TIEG1 ubiquitination leads to transcriptional activation of Foxp 3 by direct interaction of TIEG1 with the GC-rich sequences in the Foxp 3 promoter. However, we cannot exclude the possibility that TIEG1 may exert its biological function by other mechanisms, such as by forming a complex with other transcription factors to induce Foxp3 expression. Examples of such transcription factor interactions include the association of NFAT with Foxp3 and of Runx 1 with Foxp3; such interactions enhance the function of $\mathrm{T}_{\text {reg }}$ cells 27,28 .

Several proteins have been identified as substrates for Itch, with JunB and c-Jun being the most extensively studied ${ }^{19,29}$. Conjugation of ubiquitin to JunB or c-Jun leads to their degradation after $\mathrm{T}$ cell stimulation, which is associated with the transcriptional regulation of $\mathrm{T}_{\mathrm{H}} 2$ cytokines 19,29 . To determine whether Itch-mediated Jun protein ubiquitination is involved in Foxp3 expression and $\mathrm{T}_{\text {reg }}$ cell function, we did JunB and c-Jun small interfering RNA 'knockdown' experiments and found that lower expression of JunB and c-Jun in wild-type and $\mathrm{Itch}^{-/-} \mathrm{T}$ cells did not affect Foxp3 expression. Another E3 ligase, Cbl-b, has also been linked to Foxp3 expression ${ }^{30}$. It seems that Cbl-b does not directly associate with TIEG1, which suggests that Itch has a unique function in regulating TIEG1-mediated Foxp3 expression.

Like JunB, many transcription factors have been shown to undergo proteasome-dependent degradation, which is considered a counterbalancing mechanism for tight control of transcriptional responses ${ }^{31}$. Here we have provided evidence that conjugation of ubiquitin to TIEG1 did not lead to its degradation. Instead, ubiquitin modification promoted its transcriptional activation at the Foxp 3 promoter. This phenomenon has been noted for other transcription factors such as VP16 and the human immunodeficiency virus-derived Tat proteins ${ }^{32,33}$. One issue with those studies is that they used only artificial systems to test the function of ubiquitin in transcriptional activation. Although the exact mechanisms remain insufficiently clear to explain the ubiquitin-dependent control of transcription, our study has provided genetic evidence that such modification indeed positively regulates TIEG1-mediated Foxp3 expression. 
We noted that Itch promoted conjugation of ubiquitin to TIEG1 in both mono- and polyubiquitinated forms. We hypothesize that the monoubiquitinated form is crucial for TIEG1 to exert transcriptional activity, an idea supported by the finding of monoubiquitinated TIEG1 in the nuclear fraction. In contrast, a published study has documented that the E3 ligase SIAH1 targets TIEG1 ubiquitination and subsequent degradation ${ }^{34}$. It may be possible that in physiological conditions, Itch mainly induces TIEG1 monoubiquitination without affecting its protein stability. Such an idea is also consistent with published studies showing that monoubiquitination enhances transactivation ${ }^{35}$. However, it may also be possible that monoubiquitination of TIEG1 modulates its translocation to the nucleus, an idea supported by the demonstration that monoubiquitination of PTEN facilitates its nuclear import and tumor suppression $^{36}$. More notably, we found that Itch-promoted TIEG1 monoubiquitination was enhanced mainly by the coexpression of an activated TGF- $\beta$ receptor, reinforcing the idea that 'monoconjugation' of ubiquitin to TIEG1 is critical for exertion of its transactivation of Foxp3 expression. The E3 ligase activity of Itch is tightly controlled by phosphorylation, particularly by the MEKK1 kinase-Jnk kinase signaling pathway 29,37 . At present, we do not know whether the TGF- $\beta$ receptor directly affects the E3 ligase activity of Itch or does so by activating 'downstream' kinases, including MEKK1. Nevertheless, our study paves the way for future exploration of the regulatory mechanisms underlying Itch-TIEG1-regulated Foxp3 expression in the context of TGF- $\beta$ signaling.

A published study has shown that attenuated Foxp3 expression drives conventional CD4 ${ }^{+} \mathrm{T}$ cells into $\mathrm{T}_{\mathrm{H}} 2$ type effector $\mathrm{T}$ cells, manifested by higher IL-4 production ${ }^{38}$, a phenomenon similar to that of $I t \mathrm{ch}^{-1-} \mathrm{T}$ cells ${ }^{19}$. It may be possible that the lower Foxp3 expression in Itch ${ }^{-1-} \mathrm{T}$ cells after chronic antigen exposure facilitates $\mathrm{T}_{\mathrm{H}} 2$ development, in addition to the direct involvement of Itch in modulating the transcription of genes encoding $\mathrm{T}_{\mathrm{H}} 2$ cytokines, as reported before ${ }^{19}$. Indeed, chronic exposure to low-dose antigen failed to suppress airway inflammation in $\mathrm{Itch}^{-/-}$mice, accompanied by excessive T cell proliferation and less generation of CD4 ${ }^{+}$TGF- $\beta^{+}$inducible $\mathrm{T}_{\text {reg }}$ cells. In addition, TGF- $\beta$-converted $\mathrm{T}_{\text {reg }}$ cells from Itch $^{-/}$mice were not effective in inhibiting airway inflammation. Therefore, a combinatory function of Itch in conventional $\mathrm{T}$ cells and in $\mathrm{T}_{\text {reg }}$ cells tightly regulates the $\mathrm{T}_{\mathrm{H}} 2$ differentiation, and loss of Itch results in excessive $\mathrm{T}_{\mathrm{H}}$ 2-mediated allergic responses. Thus, the identification of TIEG1 as target of Itch in regulating the generation and function of $\mathrm{T}_{\text {reg }}$ cells may provide new insights into the search for additional therapeutic targets for immunological diseases.

\section{METHODS}

Mice

Itch ${ }^{-1-}$ C57BL/6 mice, originally from the laboratory of N. Jenkins (), have been described ${ }^{19}$. Mouse genotypes were identified by PCR. TIEG1-deficient mice have been described ${ }^{24}$. Mice $8-12$ week of age were used for experiments. The mice did not develop any apparent abnormality by least at 4 months of age in the animal facility. Animal experiments were done according to institutional guidelines approved by the Animal Care Committee of the La Jolla Institute for Allergy and Immunology.

\section{Antibodies}

Antibodies to Smad2 (sc-6200), Smad2-Smad3 (sc-6033), Smad4 (sc-7154), TGF- $\beta R 1$ (sc-9048), Myc (sc-40), hemagglutinin (sc-57592), TIEG1 (sc-23159), actin (sc-1616) and Grb2 (sc-2550) were from Santa Cruz Biotechnology. Monoclonal antibody to Itch (611198) was from Transduction Laboratories. Anti-Xpress (R910-25) was from Invitrogen. Antibody to phosphorylated Smad2 (3108) was from Cell Signaling. Biotin-labeled anti-TGF- $\beta$ (555052), phycoerythrin-labeled anti-CD4 (550630), allophycocyanin-labeled anti-CD25 (340938), phycoerythrin-labeled anti-GITR (558119) and phycoerythrin-labeled anti-CTLA-4 
(555853) were from BD PharMingen. Anti-Foxp3 and phycoerythrin-labeled anti-Foxp3

(12-57773) were from eBioscience.

\section{Flow cytometry}

For cell surface staining, cells were incubated with phycoerythrin- or fluorescein isothiocyanate-labeled anti-CD4; allophycocyanin-labeled anti-CD25; phycoerythrin-labeled anti-CTLA-4; phycoerythrin-labeled anti-GITR; or biotin-labeled anti-TGF- $\beta$. Membranebound anti-TGF- $\beta$ was visualized with streptavidin-phycoerythrin. For intracellular staining, Fc receptors were blocked with mouse Fc block (BD PharMingen). Cells were then fixed and made permeable with a Cytofix/Cytoperm kit (BD Pharmingen). Samples were fixed in 2\% (vol/vol) paraformaldehyde, followed by staining with phycoerythrin-labeled anti-Foxp3 or anti-CTLA-4. Cells were analyzed by flow cytometry.

\section{Isolation of $\mathrm{CD}^{+}{ }^{+} \mathrm{CD} 25^{+}$and $\mathrm{CD}^{+}{ }^{+} \mathrm{CD} 25^{-} \mathrm{T}$ cells}

$\mathrm{CD} 4^{+} \mathrm{CD} 25^{+} \mathrm{T}_{\text {reg }}$ cells were isolated by flow cytometry sorting. Spleen and lymph node cells from $\mathrm{Itch}^{+/+}$and $\mathrm{Itch}^{-/-}$mice were stained with fluorescein isothiocyanate-labeled anti-CD4 and allophycocyanin-labeled anti-CD25. CD $4{ }^{+} \mathrm{CD} 25^{-}$cells and $\mathrm{CD} 4^{+} \mathrm{CD} 25^{+}$cells were sorted by flow cytometry. In a few experiments, $\mathrm{CD} 4^{+} \mathrm{CD} 25^{+}$cells were isolated with a $\mathrm{CD} 4^{+} \mathrm{CD} 25^{+}$Regulatory $\mathrm{T}$ Cell Isolation kit (Miltenyi Biotech). The purity of isolated cells was $92-98 \%$.

\section{In vitro suppression assay}

$\mathrm{CD} 4{ }^{+} \mathrm{CD} 25^{-}$cells $\left(5 \times 10^{4}\right)$ and an equal number regulatory $\mathrm{T}$ cells (natural or TGF- $\beta$-induced) were cultured together for $72 \mathrm{~h}$ at $37^{\circ} \mathrm{C}$ in $200 \mu \mathrm{lPMI}$ medium plus $10 \%$ (vol/vol) FBS. Cultures were pulsed with $1 \mu \mathrm{Ci}\left[{ }^{3} \mathrm{H}\right]$ thymidine per well (Amersham Life Sciences) for the final 10-12 h of culture. Thymidine incorporation was analyzed with a scintillation counter. In some experiments, responder $\mathrm{CD} 4{ }^{+} \mathrm{CD} 25^{-}$cells were labeled with $\mathrm{CFSE}$ (carboxyfluorescein diacetate succinimidyl diester) or the red fluorescent cell linker PKH26 (Paul Karl Horan 26 dye). Cells $\left(1 \times 10^{7}\right)$ were resuspended in $1 \mathrm{ml} \mathrm{PBS} \mathrm{containing} 0.1 \%$ (wt/ vol) BSA and $5 \mu \mathrm{M}$ CFSE (Molecular Probes) or $2 \mu \mathrm{M}$ PKH26 (Sigma-Aldrich) and were incubated for $10 \mathrm{~min}$ at $37^{\circ} \mathrm{C}$. Labeling was stopped by the addition of $1 \mathrm{ml} \mathrm{FBS}$, then cells were washed twice with PBS. These CFSE- or PKH26-labeled responder cells were cultured together with $\mathrm{T}_{\text {reg }}$ cells. Inhibition of proliferation was measured by analysis of the dilution of CFSE or PKH26 by flow cytometry.

\section{Real time PCR}

Total RNA from $\mathrm{CD} 4{ }^{+} \mathrm{CD} 25^{-}$and $\mathrm{CD} 4{ }^{+} \mathrm{CD} 25^{+}$cells isolated from Itch $^{+/+}$and $I t c h^{-/-}$mice was isolated with TRIzol, as described ${ }^{21}$. The abundance of mRNA was normalized to that of Hprtl mRNA (encoding hypoxanthine guanine phosphoribosyl transferase). The following primers were used: Foxp 3, 5'-GGCCCTTCTCCAGGACAGA-3' (forward) and 5'-GCTGAT CATGGCTGGGTTGT-3' (reverse); and Hprt1, 5'-AGCCTAAGATGAGCG CAAGT-3' (forward) and 5'-TTACTAGGCAGATGGCCACA-3' (reverse).

\section{Plasmids and cell transfection}

Mouse TIEG1 (Klf10) cDNA was cloned by PCR and was subcloned into pcDNA3 with a Myc tag or into retroviral vector pMAX-ires-GFP. Plasmids encoding Xpress-tagged Itch, the ligase-inactive mutant Itch-CA, hemagglutinin-tagged ubiquitin cDNA, Smad2, Smad7, TGF$\beta$ receptor type I and type II, and the constitutively active TGF- $\beta$ receptor 1 have been described 39,40 . The retroviral vectors $\mathrm{pHSpG}$ and $\mathrm{pHSpG}-\mathrm{Foxp} 3$ and the Foxp3 promoter reporter pGL-Foxp3-luc have been described 41,42 . The retroviral RNA-mediated interference 'knockdown' vector pSuper-Jun-B-CFP has been described ${ }^{21}$. The pSuper-c-Jun vector was 
inserted with a pCMV-YFP unit. For expression in 293T cells or human Jurkat T cells, cells were transfected with the appropriate amount of plasmid (usually 3-5 $\mu \mathrm{g}$ total) by electroporation (240V, $960 \mu \mathrm{F}$; Bio-Rad) or with the Fugene 6 transfection reagent (Roche).

\section{Immunoprecipitation, immunoblot and precipitation assays}

For detection of the interaction of Itch and TIEG1, CD4 ${ }^{+} \mathrm{CD} 25^{-}$cells were stimulated with TGF- $\beta$ ( $5 \mathrm{ng} / \mathrm{ml}$; R\&D Systems) and then were lysed with Nonidet-P40 lysis buffer. Cell lysates were incubated for $2 \mathrm{~h}$ with $1 \mu \mathrm{g}$ anti-Itch or anti-TIEG1. This was followed by incubation for $1 \mathrm{~h}$ at $4{ }^{\circ} \mathrm{C}$ with $30 \mu \mathrm{l}$ protein G-Sepharose beads (Santa Cruz Biotechnology).

Immunoprecipitates were washed five times with Nonidet-P40 lysis buffer, then were separated by $10 \%$ SDS-PAGE and electrotransferred onto nitrocellulose membranes. Membranes were hybridized to anti-Itch or anti-TIEG1, then were washed and visualized with enhanced chemiluminescence detection system (Amersham Pharmacia). Membranes were stripped by incubation for $45 \mathrm{~min}$ at $70^{\circ} \mathrm{C}$, with constant agitation, in a buffer of $62.5 \mathrm{mM}$ Tris- $\mathrm{HCl}, \mathrm{pH}$ $6.7,100 \mathrm{mM}$ 2-mercaptoethanol and 2\% (wt/vol) SDS, then were washed and then reprobed with other antibodies.

GST-TIEG1 and GST-WW fusion proteins were expressed and purified as described ${ }^{39}$. For precipitation assays, $5 \mu \mathrm{g}$ GST fusion protein was incubated for $2 \mathrm{~h}$ at $4{ }^{\circ} \mathrm{C}$ with cell lysates, followed by the addition for $1 \mathrm{~h}$ of $30 \mu \mathrm{l}$ of glutathione-Sepharose beads (Amersham Pharmacia). Precipitates were washed five times with lysis buffer, then were separated by $10 \%$ SDS-PAGE and analyzed by immunoblot with anti-Itch or anti-TIEG1.

\section{Retroviral transduction}

$\mathrm{CD} 4^{+} \mathrm{CD} 25^{-}$cells isolated by flow cytometry sorting or with MACS beads (Miltenyi Biotech) were stimulated for $24 \mathrm{~h}$ with immobilized anti-CD3 $(5 \mu \mathrm{g} / \mathrm{ml})$ and anti-CD28 $(1 \mu \mathrm{g} / \mathrm{ml})$. Cells were infected by being mixed with green fluorescent protein (GFP)-tagged viral constructs supplemented with recombinant IL-2 $(100 \mathrm{U} / \mathrm{ml})$ and Polybrene $(2.5 \mu \mathrm{g} / \mathrm{ml})$, followed by centrifugation for $1 \mathrm{~h}$ at $700 \mathrm{~g}$. Cells were cultured for $4 \mathrm{~h}$ at $32^{\circ} \mathrm{C}$ and then for $20 \mathrm{~h}$ at $37^{\circ} \mathrm{C}$. Infections were repeated $24 \mathrm{~h}$ after the initial infection. Cells were cultured for additional $3 \mathrm{~d}$. $\mathrm{GFP}^{+}$cells were sorted by flow cytometry.

\section{Reporter assay}

For the luciferase assay, Jurkat $\mathrm{T}$ cells $\left(1 \times 10^{6}\right)$ were transfected by electroporation with a plasmid mixture including pGL3-Foxp3-Luc, $\beta$-galactosidase internal control, Smad 2 and TGF- $\beta$ receptors (I and II), together with empty vector, Itch or Itch-CA plasmids. After overnight transfection, cells were stimulated for $24 \mathrm{~h}$ with TGF- $\beta$, then were washed in PBS and lysed. The Berthold Autolumat Plus and Molecular Devices SpectraMax 250 were used for luciferase and $\beta$-galactosidase assays, respectively. Results are expressed in arbitrary luciferase units normalized to $\beta$-galactosidase activity in the same cells.

\section{Ubiquitination assay}

For detection of ubiquitination of TIEG1, 293T cells were transfected with various constructs; then, $48 \mathrm{~h}$ later, $4 \times 10^{6}$ cells were lysed in $100 \mu \mathrm{l}$ denaturation buffer $(1 \%$ (vol/vol) NonidetP40, $20 \mathrm{mM}$ Tris-HCl, pH 7.5, $150 \mathrm{mM} \mathrm{NaCl}, 5 \mathrm{mM}$ EDTA, $5 \mathrm{mM}$ NaPiP, $5 \mathrm{mM}$ sodium orthovanadate and $10 \mu \mathrm{g} / \mathrm{ml}$ each of aprotinin and leupeptin), to which SDS was added up to a concentration of $1 \%$. Cell lysates were boiled for $10 \mathrm{~min}$ to disrupt nonspecific protein-protein interactions. Denatured samples were diluted in $900 \mu \mathrm{l}$ lysis buffer, and insoluble materials were removed by centrifugation for $10 \mathrm{~min}$ at $4{ }^{\circ} \mathrm{C}$ and $15,000 \mathrm{~g}$. Cell lysates were then immunoprecipitated and blotted as described. 


\section{EMSA}

$\mathrm{CD} 4^{+} \mathrm{T}$ cells were left unstimulated or were stimulated with anti-CD3 plus anti-CD28 and recombinant TGF- $\beta(5 \mathrm{ng} / \mathrm{ml})$. Nuclear extracts were prepared by incubation of cells with buffer containing $10 \mathrm{mM}$ HEPES, pH 7.9, $10 \mathrm{mM} \mathrm{KCl}, 2 \mathrm{mM} \mathrm{MgCl}_{2}, 0.1 \mathrm{mM}$ EDTA, $1 \mathrm{mM}$ dithiothreitol and protease inhibitors. Cells were then 'spun down' for $5 \mathrm{~min}$ at 2,000g. Nuclear pellets were resuspended in extraction buffer containing $20 \mathrm{mM}$ HEPES, pH 7.9, $1.5 \mathrm{mM}$ $\mathrm{MgCl}_{2}, 0.2 \mathrm{mM}$ EDTA, $0.63 \mathrm{M} \mathrm{NaCl}, 25 \%$ (vol/vol) glycerol, 1\% (vol/vol) Nonidet-P40, 0.5 $\mathrm{mM}$ dithiothreitol and protease inhibitors. Lysed nuclei were centrifuged for $30 \mathrm{~min}$ at $15,000 \mathrm{~g}$. For gel-shift assays, nuclear extracts were incubated with ${ }^{32} \mathrm{P}$-labeled doublestranded oligonucleotides containing the GC-rich sequences in the promoter region of Foxp3 (5'-AAAACTACAA GAACCCCCCCCCCACCCTGCAATTATCAGCAC-3'). Binding reactions were done at $25^{\circ} \mathrm{C}$. For antibody supershift reactions, $1 \mu \mathrm{g}$ anti-TIEG1, antihemagglutinin (Santa Cruz Biotechnology) or control goat serum was added to the binding reaction mixture. Protein-DNA reaction mixtures were separated by 5\% PAGE and were analyzed by autoradiography.

\section{Chromatin immunoprecipitation assays}

A chromatin-immunoprecipitation assay kit (Upstate-Millipore) was used according to the manufacturer's instructions for these assays. $\mathrm{CD} 4^{+} \mathrm{CD} 25^{-}$cells $\left(2.5 \times 10^{6}\right)$ isolated from $\mathrm{Itch}^{+/+}$and $\mathrm{Itch}^{-/-}$mice were stimulated with anti-CD3 plus anti-CD28 and TGF- $\beta(5 \mathrm{ng} / \mathrm{ml})$, then cells were fixed with $1 \%(\mathrm{vol} / \mathrm{vol})$ formaldehyde and chromatin was fragmented by sonication. Sheared chromatin was precleared with salmon sperm DNA and protein A-agarose. Precleared chromatin was immunoprecipitated by overnight incubation at $4{ }^{\circ} \mathrm{C}$ with $2 \mu \mathrm{g}$ control normal goat serum or anti-TIEG1 followed by incubation for $2 \mathrm{~h}$ with protein Aagarose. Precipitates were then 'defixed' and DNA was purified by phenol-chloroform extraction. The immunoprecipitated Foxp3 promoter DNA (331 base pairs) was amplified by PCR with the primer pair 5'-GACTCAAGGGGGTCTCA-3' (forward) and 5'TTGGGCTTCATCGGCAA-3' (reverse), as described ${ }^{42}$.

\section{Adoptive transfer and allergy induction}

TIEG1-wild-type and TIEG1-deficient $\mathrm{CD} 4{ }^{+} \mathrm{CD} 25^{-}$cells were sorted and were transduced with retrovirus containing empty vector or TIEG1, then Foxp3 expression was induced by treatment with TGF- $\beta$ as described above. GFP ${ }^{+}$cells were sorted by flow cytometry and were injected intravenously into naive C57BL/6 mice $\left(2.5 \times 10^{6}\right.$ cells per mouse). Recipient mice were immunized with OVA $(20 \mu \mathrm{g} / \mathrm{ml})$ plus alum $(2 \mathrm{mg} / \mathrm{ml})$. Between day 14 and day 20 , mice were challenged intranasally with aerosolized OVA. Mice were killed and bronchoalveolar lavage was done on the same day at $3 \mathrm{~h}$ after the final OVA exposure. Cytokine concentrations were measured in bronchoalveolar lavage fluid by enzyme-linked immunosorbent assay, and cell differentials were assessed as described ${ }^{21}$. OVA-specific IgE was measured by enzymelinked immunosorbent assay. Values were converted to arbitrary units with pooled sera from immunized mice, with high IgE titer as a standard. For proliferation, cytokine production, cell numbers and $\operatorname{IgE}$ concentration, values were calculated as mean and s.d. for at least three separate experiments done in triplicate.

\section{Acknowledgements}

We thank W. Zhang (Duke University) for providing Foxp3 retroviral vector, and J. Huehn (Berlin, Germany) for the Foxp3-luciferase reporter plasmid. Supported by the National Institutes of Health (Y.-C.L.). 


\section{References}

1. Wills-Karp M. Immunologic basis of antigen-induced airway hyperresponsiveness. Annu Rev Immunol 1999;17:255-281. [PubMed: 10358759]

2. Umetsu DT, McIntire JJ, Akbari O, Macaubas C, DeKruyff RH. Asthma: an epidemic of dysregulated immunity. Nat Immunol 2002;3:715-720. [PubMed: 12145657]

3. Herrick CA, Bottomly K. To respond or not to respond: T cells in allergic asthma. Nat Rev Immunol 2003;3:405-412. [PubMed: 12766762]

4. McMenamin C, Pimm C, McKersey M, Holt PG. Regulation of IgE responses to inhaled antigen in mice by antigen-specific $\gamma \delta$ T cells. Science 1994;265:1869-1871. [PubMed: 7916481]

5. Ostroukhova $\mathrm{M}$, et al. Tolerance induced by inhaled antigen involves $\mathrm{CD} 4^{+} \mathrm{T}$ cells expressing membrane-bound TGF- $\beta$ and FOXP3. J Clin Invest 2004;114:28-38. [PubMed: 15232609]

6. Mucida D, et al. Oral tolerance in the absence of naturally occurring Tregs. J Clin Invest 2005;115:1923-1933. [PubMed: 15937545]

7. Sakaguchi S. Naturally arising $\mathrm{CD}^{+}{ }^{+}$regulatory $\mathrm{T}$ cells for immunologic self-tolerance and negative control of immune responses. Annu Rev Immunol 2004;22:531-562. [PubMed: 15032588]

8. Fontenot JD, Rudensky AY. A well adapted regulatory contrivance: regulatory T cell development and the forkhead family transcription factor Foxp3. Nat Immunol 2005;6:331-337. [PubMed: 15785758]

9. Li MO, Wan YY, Sanjabi S, Robertson AK, Flavell RA. Transforming growth factor- $\beta$ regulation of immune responses. Annu Rev Immunol 2006;24:99-146. [PubMed: 16551245]

10. Kulkarni AB, et al. Transforming growth factor B1 null mutation in mice causes excessive inflammatory response and early death. Proc Natl Acad Sci USA 1993;90:770-774. [PubMed: 8421714]

11. Li MO, Sanjabi S, Flavell RA. Transforming growth factor- $\beta$ controls development, homeostasis, and tolerance of $\mathrm{T}$ cells by regulatory $\mathrm{T}$ cell-dependent and -independent mechanisms. Immunity 2006;25:455-471. [PubMed: 16973386]

12. Marie JC, Liggitt D, Rudensky AY. Cellular mechanisms of fatal early-onset autoimmunity in mice with the T cell-specific targeting of transforming growth factor- $\beta$ receptor. Immunity $2006 ; 25: 441-$ 454. [PubMed: 16973387]

13. Shull MM, et al. Targeted disruption of the mouse transforming growth factor- $\beta 1$ gene results in multifocal inflammatory disease. Nature 1992;359:693-699. [PubMed: 1436033]

14. Chen $\mathrm{W}$, et al. Conversion of peripheral $\mathrm{CD} 4{ }^{+} \mathrm{CD} 25^{-}$naive $\mathrm{T}$ cells to $\mathrm{CD} 4{ }^{+} \mathrm{CD} 25^{+}$regulatory $\mathrm{T}$ cells by TGF- $\beta$ induction of transcription factor Foxp3. J Exp Med 2003;198:1875-1886. [PubMed: 14676299]

15. Fantini MC, et al. Cutting edge: TGF- $\beta$ induces a regulatory phenotype in $\mathrm{CD} 4{ }^{+} \mathrm{CD} 25^{-} \mathrm{T}$ cells through Foxp3 induction and down-regulation of Smad7. J Immunol 2004;172:5149-5153. [PubMed: 15100250]

16. Wan YY, Flavell RA. Identifying Foxp3-expressing suppressor T cells with a bicistronic reporter. Proc Natl Acad Sci USA 2005;102:5126-5131. [PubMed: 15795373]

17. Weaver CT, Hatton RD, Mangan PR, Harrington LE. IL-17 family cytokines and the expanding diversity of effector T cell lineages. Annu Rev Immunol 2007;25:821-852. [PubMed: 17201677]

18. Perry WL, et al. The itchy locus encodes a novel ubiquitin protein ligase that is disrupted in $\alpha^{18 \mathrm{H}}$ mice. Nat Genet 1998;18:143-146. [PubMed: 9462742]

19. Fang D, et al. Dysregulation of T lymphocyte function in itchy mice: a role for Itch in $\mathrm{TH} 2$ differentiation. Nat Immunol 2002;3:281-287. [PubMed: 11828324]

20. Heissmeyer V, et al. Calcineurin imposes $\mathrm{T}$ cell unresponsiveness through targeted proteolysis of signaling proteins. Nat Immunol 2004;5:255-265. [PubMed: 14973438]

21. Venuprasad K, et al. Convergence of Itch-induced ubiquitination with MEKK1-JNK signaling in Th2 tolerance and airway inflammation. J Clin Invest 2006;116:1117-1126. [PubMed: 16557301]

22. Hefferan TE, et al. Overexpression of a nuclear protein, TIEG, mimics transforming growth factor$\beta$ action in human osteoblast cells. J Biol Chem 2000;275:20255-20259. [PubMed: 10816551] 
23. Hefferan TE, Subramaniam M, Khosla S, Riggs BL, Spelsberg TC. Cytokine-specific induction of the TGF- $\beta$ inducible early gene (TIEG): regulation by specific members of the TGF- $\beta$ family. J Cell Biochem 2000;78:380-390. [PubMed: 10861837]

24. Subramaniam M, et al. TIEG1 null mouse-derived osteoblasts are defective in mineralization and in support of osteoclast differentiation in vitro. Mol Cell Biol 2005;25:1191-1199. [PubMed: 15657444]

25. Sugimoto N, et al. Foxp3-dependent and -independent molecules specific for CD25 $5^{+} \mathrm{CD} 4^{+}$natural regulatory T cells revealed by DNA microarray analysis. Int Immunol 2006;18:1197-1209. [PubMed: 16772372]

26. Lomberk G, Urrutia R. The family feud: turning off Sp1 by Sp1-like KLF proteins. Biochem J 2005;392:1-11. [PubMed: 16266294]

27. Ono M, et al. Foxp3 controls regulatory T-cell function by interacting with AML1/Runx1. Nature 2007;446:685-689. [PubMed: 17377532]

28. Wu Y, et al. FOXP3 controls regulatory $\mathrm{T}$ cell function through cooperation with NFAT. Cell 2006;126:375-387. [PubMed: 16873067]

29. Gao M, et al. Jun turnover is controlled through JNK-dependent phosphorylation of the E3 ligase Itch. Science 2004;306:271-275. [PubMed: 15358865]

30. Wohlfert EA, Gorelik L, Mittler R, Flavell RA, Clark RB. Cutting edge: deficiency in the E3 ubiquitin ligase Cbl-b results in a multifunctional defect in T cell TGF- $\beta$ sensitivity in vitro and in vivo. $\mathrm{J}$ Immunol 2006;176:1316-1320. [PubMed: 16424156]

31. Hershko A, Ciechanover A. The ubiquitin system. Annu Rev Biochem 1998;67:425-479. [PubMed: 9759494]

32. Salghetti SE, Caudy AA, Chenoweth JG, Tansey WP. Regulation of transcriptional activation domain function by ubiquitin. Science 2001;293:1651-1653. [PubMed: 11463878]

33. Bres V, et al. A non-proteolytic role for ubiquitin in Tat-mediated transactivation of the HIV-1 promoter. Nat Cell Biol 2003;5:754-761. [PubMed: 12883554]

34. Johnsen SA, Subramaniam M, Monroe DG, Janknecht R, Spelsberg TC. Modulation of transforming growth factor $\beta$ (TGF $\beta$ )/Smad transcriptional responses through targeted degradation of TGF $\beta$ inducible early gene-1 by human seven in absentia homologue. J Biol Chem 2002;277:30754-30759. [PubMed: 12072443]

35. Greer SF, Zika E, Conti B, Zhu XS, Ting JP. Enhancement of CIITA transcriptional function by ubiquitin. Nat Immunol 2003;4:1074-1082. [PubMed: 14528304]

36. Trotman LC, et al. Ubiquitination regulates PTEN nuclear import and tumor suppression. Cell 2007;128:141-156. [PubMed: 17218261]

37. Yang $C$, et al. Negative regulation of the E3 ubiquitin ligase Itch via Fyn-mediated tyrosine phosphorylation. Mol Cell 2006;21:135-141. [PubMed: 16387660]

38. Wan YY, Flavell RA. Regulatory T-cell functions are subverted and converted owing to attenuated Foxp3 expression. Nature 2007;445:766-770. [PubMed: 17220876]

39. Qiu L, et al. Recognition and ubiquitination of Notch by Itch, a Hect-type E3 ubiquitin ligase. J Biol Chem 2000;275:35734-35737. [PubMed: 10940313]

40. Bai Y, Yang C, Hu K, Elly C, Liu YC. Itch E3 ligase-mediated regulation of TGF- $\beta$ signaling by modulating smad2 phosphorylation. Mol Cell 2004;15:825-831. [PubMed: 15350225]

41. Koonpaew S, Shen S, Flowers L, Zhang W. LAT-mediated signaling in $\mathrm{CD} 4{ }^{+} \mathrm{CD} 25^{+}$regulatory T cell development. J Exp Med 2006;203:119-129. [PubMed: 16380508]

42. Floess S, et al. Epigenetic control of the foxp3 locus in regulatory T cells. PLoS Biol 2007;5:e38. [PubMed: 17298177] 

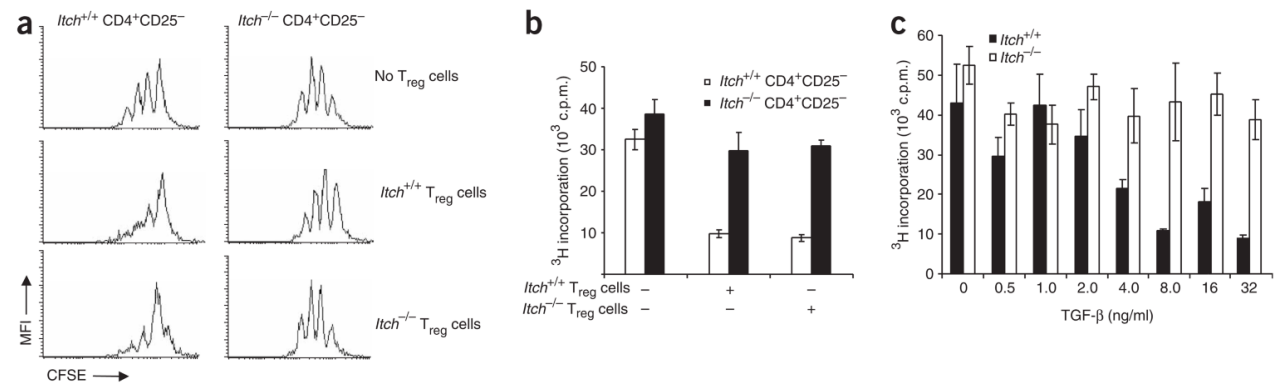

Figure 1.

Itch ${ }^{-1-} \mathrm{CD} 4{ }^{+} \mathrm{CD} 25^{-}$cells are resistant to TGF- $\beta$-mediated suppression. (a) Flow cytometry of CFSE dilution in Itch ${ }^{+/+}$and $I t c h^{-/-} \mathrm{CD} 4{ }^{+} \mathrm{CD} 25^{-}$responder cells labeled with CFSE, cultured with $I t c h^{+/+}$or $I t c h^{-1-} \mathrm{CD} 4{ }^{+} \mathrm{CD} 25^{+} \mathrm{T}_{\text {reg }}$ cells and irradiated $\mathrm{T}$ cell-depleted splenocyte samples, then stimulated with anti-CD3 $(1 \mu \mathrm{g} / \mathrm{ml})$ and cultured for $72 \mathrm{~h}$. MFI, mean fluorescence intensity. (b) The inhibitory function of $\mathrm{T}_{\text {reg }}$ cells, analyzed by measurement of ${ }^{3}[\mathrm{H}]$ thymidine incorporation by $\mathrm{CD} 4{ }^{+} \mathrm{CD} 25^{-}$cells and $\mathrm{CD} 4{ }^{+} \mathrm{CD} 25^{+}$cells cultured together as described in a. (c) Proliferation of CD $4{ }^{+} \mathrm{CD} 25^{-}$cells isolated from $\mathrm{Itch}^{+/+}$and $\mathrm{Itch}{ }^{-/-}$mice, stimulated with anti-CD3 plus anti-CD28 and various concentrations of recombinant TGF- $\beta$ and cultured for $72 \mathrm{~h}$, analyzed by measurement of ${ }^{3}[\mathrm{H}]$ thymidine incorporation. Data are representative of three independent experiments (mean \pm s.d., b,c). 


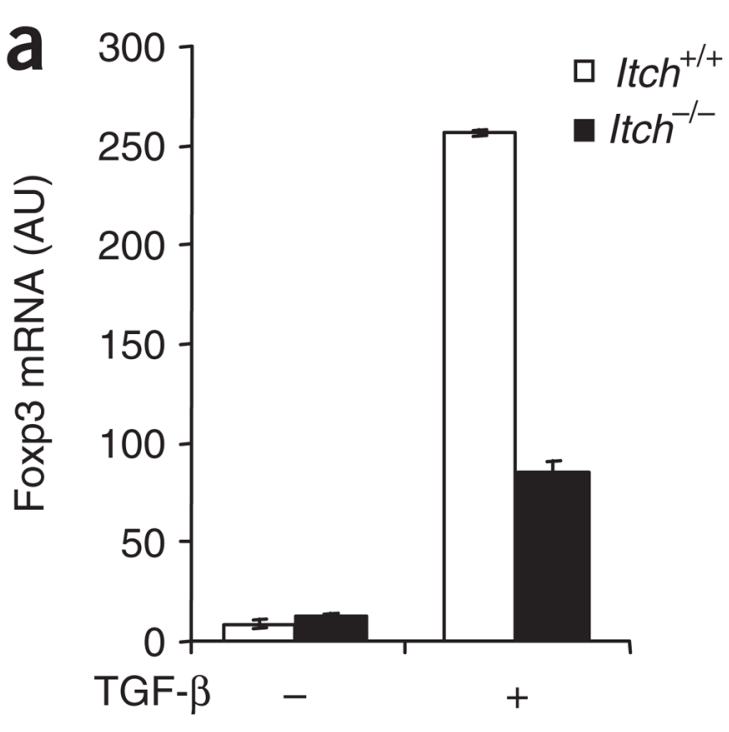

d

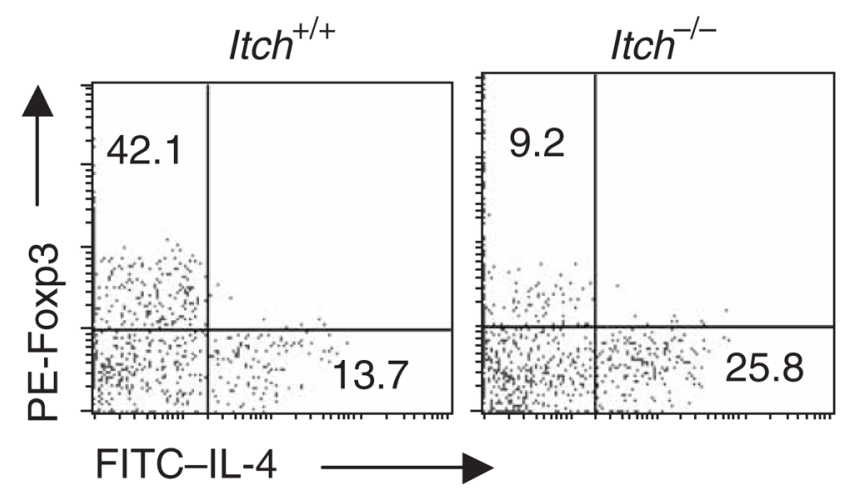

b $T$ TGF- $\beta$

Itch
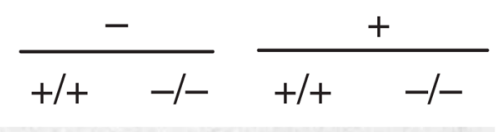

Foxp3

Actin
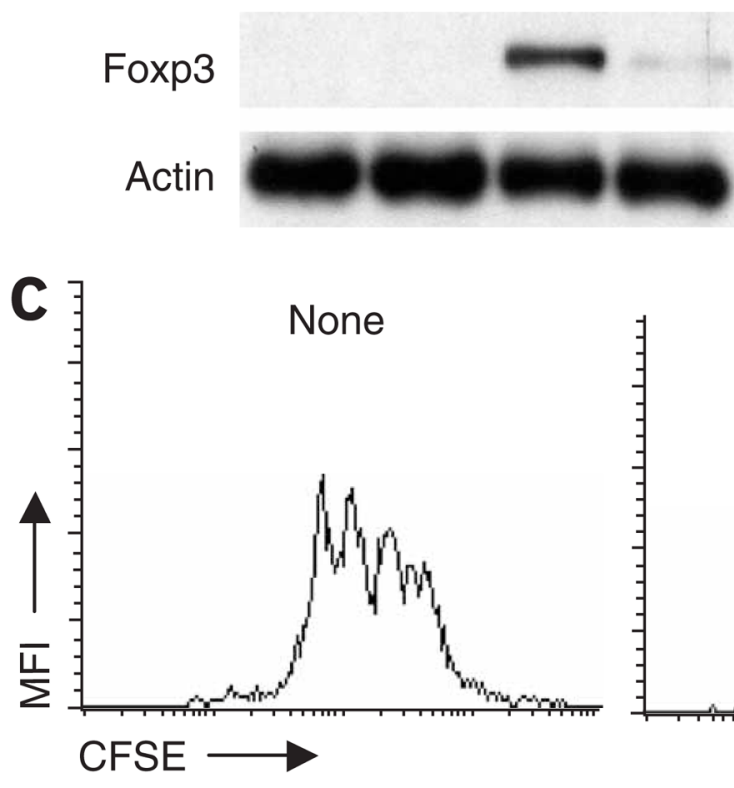

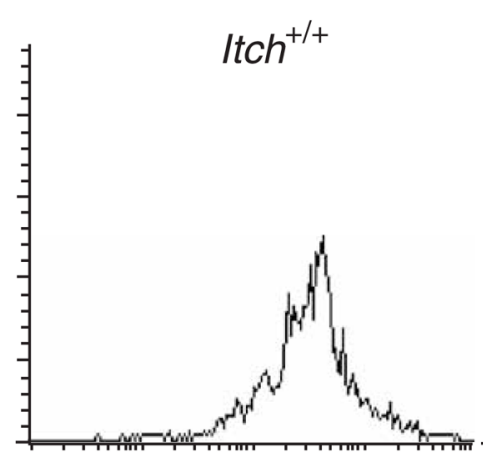

e

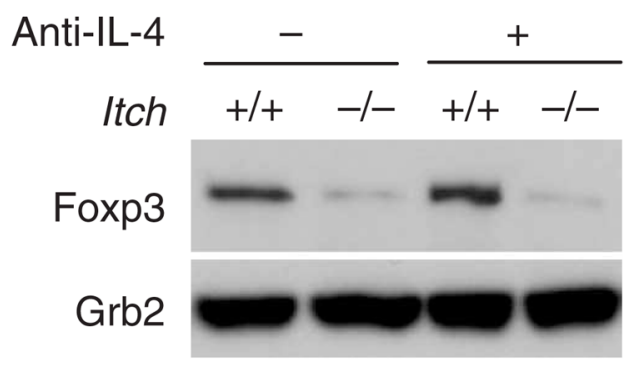

Itch $^{-/}$

Figure 2.

Itch regulates Foxp3 expression in TGF- $\beta$-treated $\mathrm{CD} 4^{+} \mathrm{CD} 25^{-}$cells. (a) Real-time PCR analysis of Foxp 3 mRNA in CD4 ${ }^{+} \mathrm{CD} 25^{-}$cells isolated from Itch $^{+/+}$and Itch $^{-/-}$mice and stimulated with anti-CD3 plus anti-CD28 with (+) or without (-) TGF- $\beta(5 \mathrm{ng} / \mathrm{ml})$. Arbitrary units (AU) are normalized to the abundance of Hprt1 mRNA. (b) Immunoblot analysis of Foxp3 expression in an experiment similar to that in a; Foxp3 expression is normalized to that of $\beta$-actin. (c) CSFE dilution analysis of the inhibitory function of TGF- $\beta$-treated $I t c h^{+/+}$or Itch $^{-1-} \mathrm{CD} 4^{+} \mathrm{T}$ cells cultured together with $\mathrm{CD} 4^{+} \mathrm{CD} 25^{-}$responder cells isolated from Itch $^{+/+}$mice. None, Itch ${ }^{+/+}$responder cells cultured alone. (d) Flow cytometry of Itch $^{+/+}$and Itch ${ }^{-/-} \mathrm{CD} 4^{+} \mathrm{CD} 25^{-}$cells stimulated for $6 \mathrm{~d}$ with anti-CD3 plus anti-CD28 and TGF- $\beta$; live cells were then restimulated for $12 \mathrm{~h}$ with anti-CD3 plus anti-CD28, with brefeldin A added 
during the final $2 \mathrm{~h}$, then cells were stained intracellularly with fluorescein isothiocyanatelabeled anti-IL-4 (FITC-anti-IL-4) and phycoerythrin-labeled anti-Foxp3 (PE-anti-Foxp3). Numbers in quadrants indicate percent Foxp $3^{+} \mathrm{IL}-4^{-}$cells (top left) or Foxp3 $3^{-} \mathrm{IL}_{-} 4^{+}$cells (bottom right). (e) Immunoblot of lysates of $I t c h^{+/+}$and $I t c h^{--} \mathrm{CD} 4{ }^{+} \mathrm{CD} 25^{-}$cells stimulated with anti-CD3 plus anti-CD28 and TGF- $\beta$ with or without anti-IL-4 $(10 \mu \mathrm{g} / \mathrm{ml})$, analyzed with anti-Foxp3, then reprobed with anti-Grb2 (loading control). Data are representative of three independent experiments. 
a

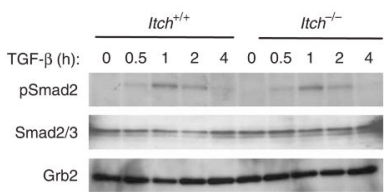

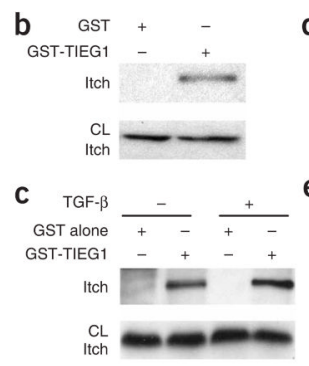

e

$\underset{\alpha-\text { TIEG1 }}{\text { NGS }}$

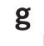

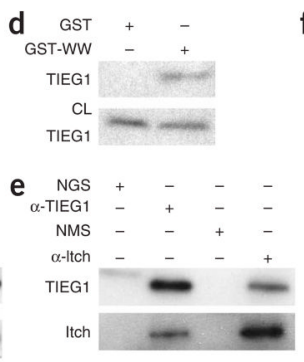

h

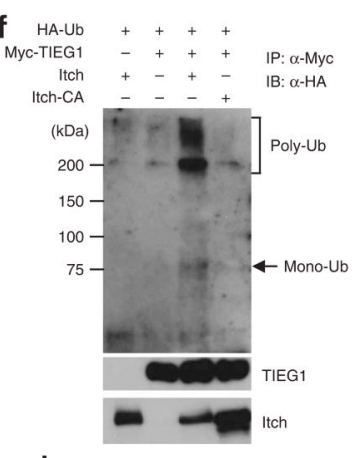

HA-Ub +++

Myc-TIEG $1+++$

Itch $++-{ }^{+}$IP: $\alpha$-Myc

Itch-CA $^{\text {TRR1 }}{ }^{*}+++$ IB: $\mathrm{\alpha}-\mathrm{HA}$

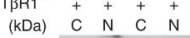

75- Mono-Ub

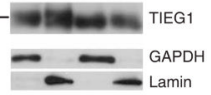

Figure 3.

Itch associates with TIEG1 and targets it for ubiquitination. (a) Immunoblot analysis of Smad2 phosphorylation in lysates of CD4 ${ }^{+} \mathrm{CD} 25^{-}$cells sorted from Itch $^{+/+}$and Itch $^{-/-}$mice and stimulated with anti-CD3 plus anti-CD28 with or without TGF- $\beta$ ( $5 \mathrm{ng} / \mathrm{ml})$, analyzed with antibody to phosphorylated Smad2 (pSmad2). Total Smad2-Smad3 ( $\operatorname{Smad} 2 / 3)$ and Grb2 serve as loading controls. (b) Immunoblot of lysates of CD4 ${ }^{+} \mathrm{CD} 25^{-}$cells precipitated with GST alone or GST-TIEG1; precipitates (top) and total cell lysates (CL; bottom) were analyzed with anti-Itch. (c) Immunoblot analysis of $\mathrm{CD} 4{ }^{+} \mathrm{CD} 25^{-}$cells left untreated or treated with TGF- $\beta$; lysates were precipitated with GST alone or GST-TIEG1, and precipitates (top) and total cell lysates (bottom) were analyzed with anti-Itch. (d) Immunoblot analysis of CD $4{ }^{+} \mathrm{CD} 25^{-}$cells treated with TGF- $\beta$; lysates were precipitated with GST alone or GST-WW and analyzed with anti-TIEG1. (e) Immunoassay of the in vivo association between Itch and TIEG1 in TGF- $\beta$ stimulated T cells; lysates were immunoprecipitated with normal goat serum (NGS), antiTIEG1 ( $\alpha$-TIEG1), normal mouse serum (NMS) or anti-Itch ( $\alpha$-Itch) and were analyzed by immunoblot with anti-TIEG1 (top) or anti-Itch (bottom). (f) Immunoassay of 293T cells transiently transfected with various plasmids (above lanes), then lysed $48 \mathrm{~h}$ later and denatured in $1 \%$ SDS; lysates were immunoprecipitated (IP) with anti-Myc and analyzed by immunoblot (IB) with anti-hemagglutinin ( $\alpha$-HA). Left margin, molecular sizes in kilodaltons $(\mathrm{kDa})$; right margin, positions of monoubiquitin (Mono-Ub) and polyubiquitin (Poly-Ub). Middle, same membrane reprobed with anti-Myc. Bottom, immunoblot analysis of aliquots of cell lysates with anti-Itch. HA-Ub, hemagglutinin-tagged ubiquitin. (g) Immunoassay of 293T cells transfected with various plasmids (above lanes) plus plasmid encoding an active form of TGF$\beta$ receptor 1 (T $\left.\beta R 1^{*}\right)$. Right margin, positions of monoubiquitin, diubiquitin $(+2)$, triubiquitin $(+3)$, quadriubiquitin (+4) and polyubiquitin. (h) Immunoprecipitation and immunoblot analysis of transfected 293T cells separated into cytoplasmic (C) and nuclear (N) fractions; GAPDH (glyceraldehyde phosphate dehydrogenase) and lamin serve as 'markers' for the cytoplasmic and nuclear fractions, respectively. Data are representative of three independent experiments. 


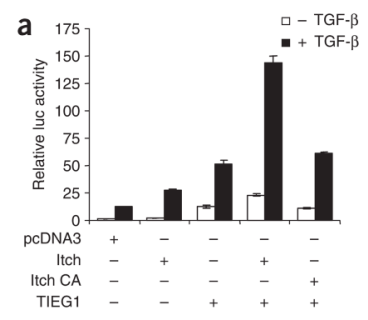

b

TGF- $\beta$
$\alpha$-TEG1
NGS
C

TGF- $\beta$ - -++

Itch $+/+-1-+1++$

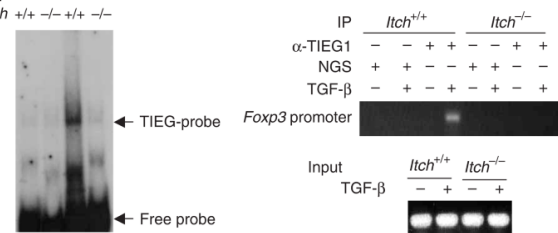

e

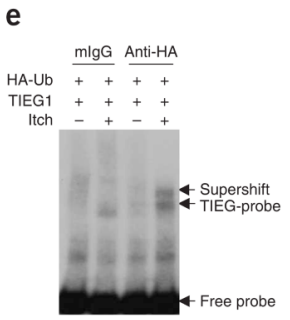

f

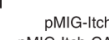
pMIG-Itch
pMIG-Itch-CA
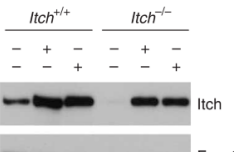

- - - Foxp3

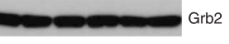

g

g pMIG-Itch - Input $\quad$ IP Itch

0000

Figure 4.

Itch-mediated ubiquitination of TIEG1 is necessary for Foxp3 expression. (a) Foxp3 promoter activity in Jurkat $\mathrm{T}$ cells transfected with the pGL3-Foxp3-Ce reporter plasmid, control vector, Itch, Itch-CA and/or TIEG1, then treated for $24 \mathrm{~h}$ with TGF- $\beta$, analyzed by measurement of luciferase (luc) activity (normalized to that of $\beta$-galactosidase). (b) EMSA of DNA-protein binding in nuclear extracts of untreated or TGF- $\beta$-treated $C D 4{ }^{+} \mathrm{CD} 25^{-}$cells mixed with radiolabeled oligonucleotide probe corresponding to a GC-rich region in the Foxp3 promoter; anti-TIEG1 or normal goat serum was used for higher-order antibody-protein complex formation 'supershifting'. Right margin, antibody-dependent 'supershifted' bands. (c) EMSA of DNA binding in nuclear lysates from untreated or TGF- $\beta$-treated Itch ${ }^{+/+}$and $\mathrm{Itch}^{-/-}$ $\mathrm{CD} 4{ }^{+} \mathrm{CD} 25^{-}$cells. (d) Chromatin immunoprecipitation assay of $\mathrm{Itch}^{+/+}$and Itch $^{-/-}$ $\mathrm{CD} 4^{+} \mathrm{CD} 25^{-}$cells; chromatin DNA obtained before (Input) and after (IP) immunoprecipitation with anti-TIEG1 or control normal goat serum was analyzed by PCR with primers specific for the Foxp3 promoter. (e) 'Supershift' assay, as described in b, of $293 \mathrm{~T}$ cells transfected with various plasmids (above lanes), analyzed with anti-hemagglutinin. mIgG, mouse IgG. (f) Immunoblot analysis of $\mathrm{Itch}^{+/+}$and Itch $^{-/-} \mathrm{CD} 4{ }^{+} \mathrm{CD} 25^{-}$cells transduced with retrovirus vector pMIG-Itch or pMIG-Itch-CA; GFP ${ }^{+}$cells sorted by flow cytometry were stimulated with antiCD3 plus anti-CD28 and TGF- $\beta$ and analyzed with anti-Foxp3. Bottom, same membrane probed with anti-Grb2 (loading control). (g) Chromatin immunoprecipitation assay of the interaction of TIEG1 with the Foxp3 promoter in cells reconstituted as described in $\mathbf{f}$. Data are representative of three repeated experiments. 
a

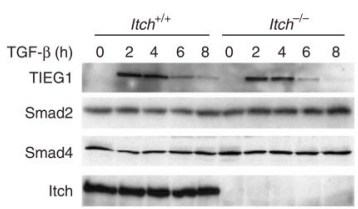

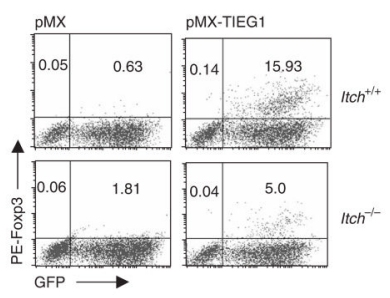

c

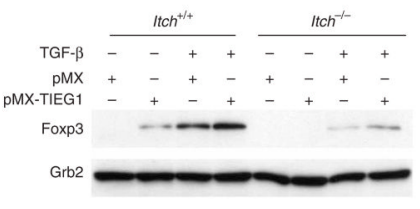

Figure 5.

TIEG1 expression restores Foxp3 expression in Itch $^{-1-} \mathrm{T}$ cells. (a) Immunoblot analysis of TIEG1, Smad 2 and Smad4 in lysates of Itch ${ }^{+/+}$and Itch $^{-1-} \mathrm{CD} 4{ }^{+} \mathrm{CD} 25^{-}$cells stimulated with anti-CD3 plus anti-CD28 with or without TGF- $\beta(5 \mathrm{ng} / \mathrm{ml})$. (b) Flow cytometry of $\mathrm{CD} 4{ }^{+} \mathrm{CD} 25^{-}$cells transduced with pMX or pMX-TIEG1, then stained intracellularly with phycoerythrin-labeled anti-Foxp3 after $6 \mathrm{~d}$. Numbers in quadrants indicate percent Foxp $3^{+} \mathrm{GFP}^{-}$cells (top left) or Foxp $3^{+} \mathrm{GFP}^{+}$cells (top right). (c) Immunoblot analysis of Foxp3 in lysates of $\mathrm{CD}^{+}{ }^{+} \mathrm{CD} 25^{-}$cells transduced with $\mathrm{pMX}$ or $\mathrm{pMX}-\mathrm{TIEG} 1$; $\mathrm{GFP}^{+}$cells were sorted by flow cytometry and treated with TGF- $\beta$. Bottom, same lysates probed with anti-Grb2 (loading control). Data are representative of three independent experiments. 


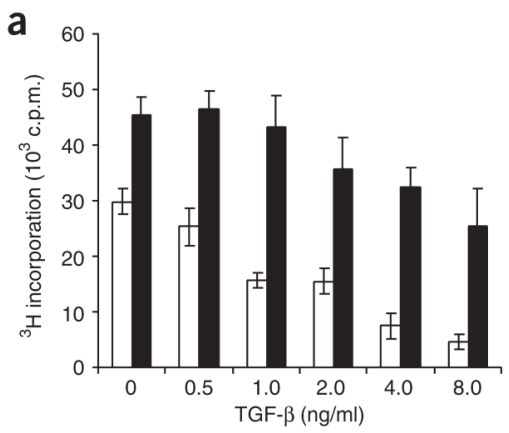

b

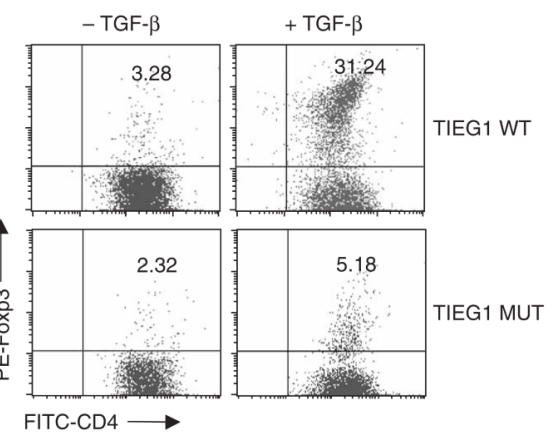

C

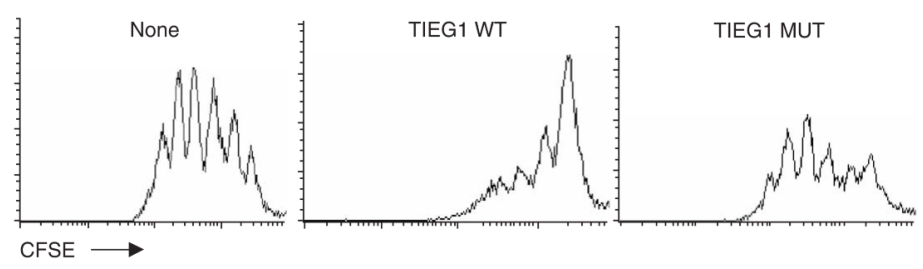

Figure 6.

TIEG1-deficient $\mathrm{T}$ cells fail to express Foxp3. (a) $\left[{ }^{3} \mathrm{H}\right]$ thymidine incorporation by $\mathrm{CD} 4^{+} \mathrm{CD} 25^{-}$cells from TIEG1-wild-type mice (open bars) and TIEG1-deficient mice (filled bars), stimulated for $72 \mathrm{~h}$ with anti-CD3 plus anti-CD28 and various concentrations of TGF$\beta$ (horizontal axis) and pulsed for the final $12 \mathrm{~h}$ with $\left[{ }^{3} \mathrm{H}\right]$ thymidine. (b) Flow cytometry of Foxp3 expression by $\mathrm{CD} 4{ }^{+} \mathrm{CD} 25^{-}$cells from TIEG1-wild-type mice (TIEG1 WT) and TIEG1deficient mice (TIEG1 MUT), stimulated for $7 \mathrm{~d}$ with anti-CD3 plus anti-CD28 with or without TGF- $\beta(5 \mathrm{ng} / \mathrm{ml})$, analyzed by intracellular staining. Numbers in the top right quadrants indicate percent Foxp $3^{+} \mathrm{CD} 4^{+} \mathrm{T}$ cells. (c) CFSE dilution by $\mathrm{CD} 4{ }^{+} \mathrm{CD} 25^{-}$cells isolated from TIEG1wild-type mice, labeled with CFSE and cultured together with TGF- $\beta$-treated TIEG1-wildtype or TIEG1-deficient T cells. Data are from one of three experiments (mean \pm s.d. of triplicate samples, a). 
a
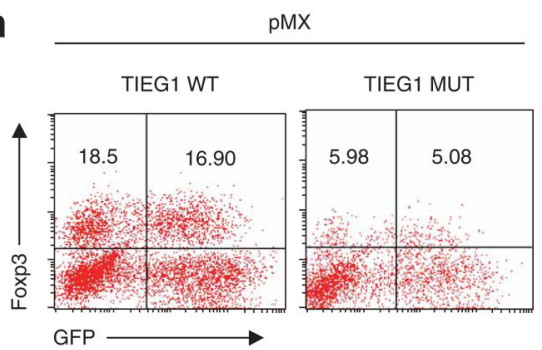

b

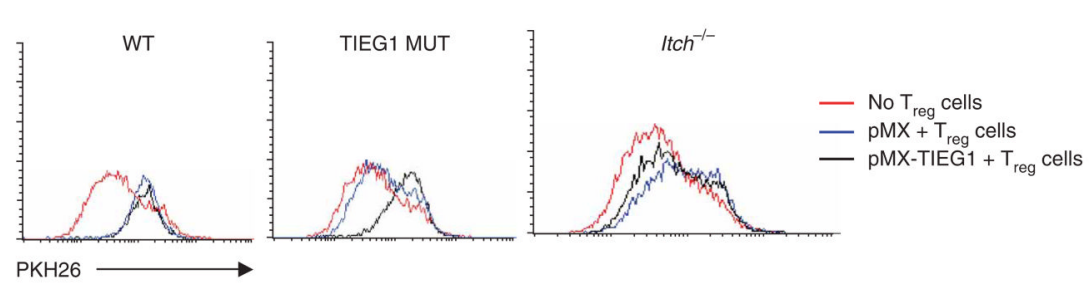

pMX-TIEG1

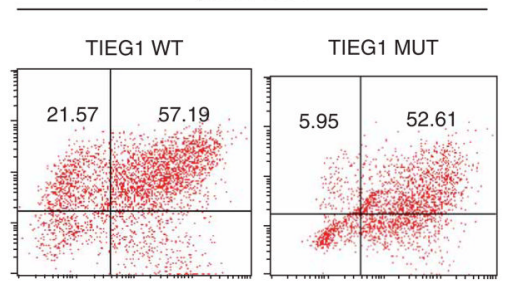

Figure 7.

Reconstitution of TIEG1 restores Foxp3 expression. (a) Flow cytometry of $\mathrm{CD} 4{ }^{+} \mathrm{CD} 25^{-}$cells sorted from TIEG1-wild-type or TIEG1-deficient mice, transduced with retroviral vector pMX (control) or pMX-TIEG1, then treated with TGF- $\beta$ and stained intracellularly with anti-Foxp3. Numbers in quadrants indicate percent Foxp $3^{+} \mathrm{GFP}^{-}$cells (top left) or Foxp $3^{+} \mathrm{GFP}^{+}$cells (top right). (b) PKH26 dilution by wild-type (WT), TIEG1-deficient and Itch ${ }^{-/} \mathrm{CD} 4{ }^{+} \mathrm{CD} 25^{-}$cells transduced with $\mathrm{pMX}$ or $\mathrm{pMX}$-TIEG1; $\mathrm{GFP}^{+}$cells sorted by flow cytometry (responder T cells) were cultured together with $\mathrm{CD} 4{ }^{+} \mathrm{CD} 25^{+} \mathrm{T}_{\text {reg }}$ cells isolated from wild-type mice to assess the responsiveness of the responder cells to $\mathrm{T}_{\text {reg }}$ cell-mediated suppression. Data represent one of three independent experiments. 

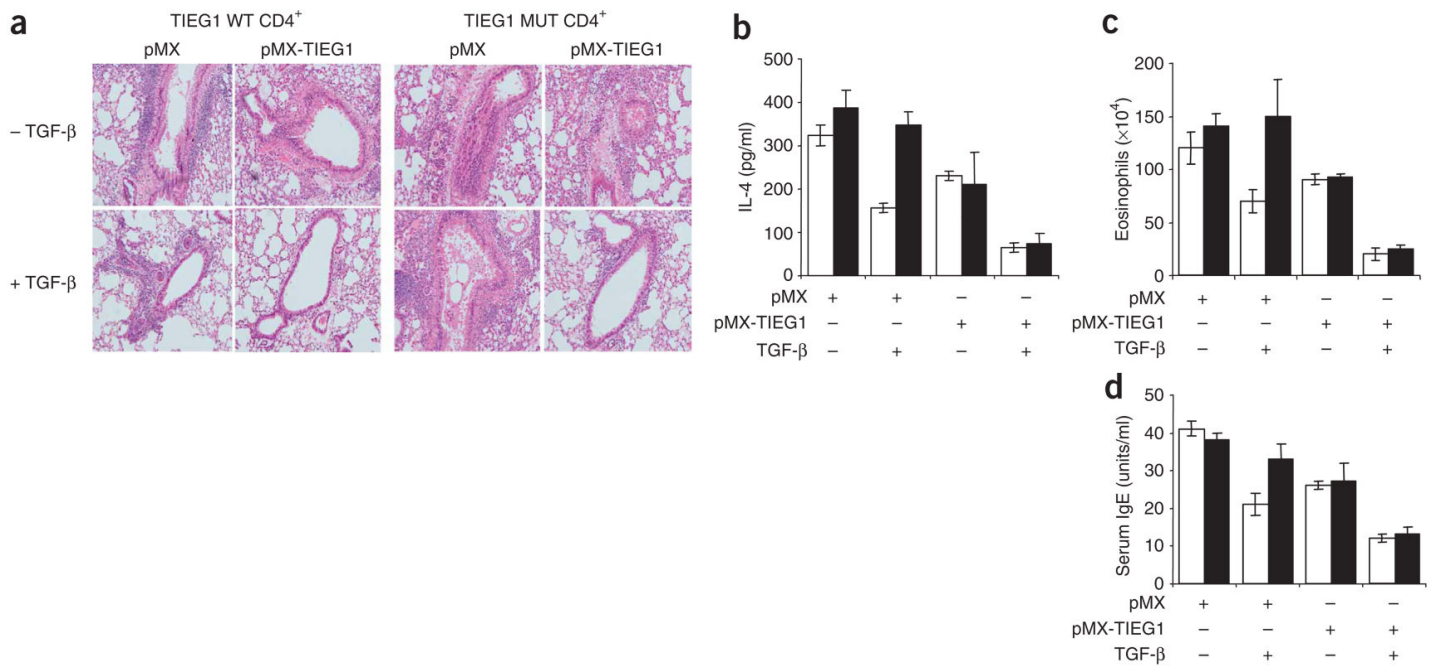

Figure 8.

TIEG1-deficient $T_{\text {reg }}$ cells are defective in inhibiting airway inflammation. $\mathrm{CD} 4{ }^{+} \mathrm{CD} 25^{-}$cells sorted from TIEG1-wild-type and TIEG1-deficient mice ( $n=4$ mice per group) were transduced with pMX or pMX-TIEG1 retrovirus and left untreated or treated with TGF- $\beta$; $\mathrm{GFP}^{+}$cells $\left(2.5 \times 10^{6}\right)$ were sorted by flow cytometry and then adoptively transferred into naive wild-type mice ( $n=4$ mice per group). Recipient mice were immunized, followed by intranasal challenge with aerosolized OVA. (a) Lung histology (hematoxylin and eosin staining). Original magnification, $\times 00$. (b,c) IL-4 concentration (b) and eosinophils (c) in bronchoalveolar lavage fluid. (d) Enzyme-linked yimmunosorbent assay of serum IgE titers. Arbitrary units were converted to a known IgE standard. (b-d) Open bars, TIEG1-wild-type; filled bars, TIEG1-deficient. Data are representative of three independent experiments (mean \pm s.d. of three samples, $\mathbf{b}-\mathbf{d}$ ). 